\title{
Thermal Simulation of a Screenhouse Proposed for Fruit and Vegetable Production in the Lowlands of Panama
}

\author{
Edwin Villagrán \\ Centro de Investigación Tibaitata, Corporación Colombiana de Investigación Agropecuaria- AGROSAVIA, Mosquera - \\ Cundinamarca 250040, Colombia
}

Corresponding Author Email: edwina.villagranm@utadeo.edu.co

https://doi.org/10.18280/ijht.390407

Received: 21 May 2020

Accepted: 24 August 2021

\section{Keywords:}

air flow, thermal differential, CFD simulation, insect proof

\begin{abstract}
In developing countries, open field agricultural production is highly vulnerable to biotic and abiotic factors limiting crop productivity, generating economic losses and affecting food security. Therefore, one of the strategies that can improve these production systems is the implementation of the crops under cover technically adapted to the climatic and socioeconomic conditions of each region. The objective of this research was to analyze the thermal behavior and airflow patterns of an insect-proof screenhouse through computational fluid dynamics simulations using a 3D model. The results obtained for the multiannual monthly climatic conditions of a warm climate region in Panama showed that the airflow velocities inside the structure were lower between 76.8 and $80.2 \%$ with respect to the external velocity. The most critical scenarios showed temperature differences below $2{ }^{\circ} \mathrm{C}$ inside the screenhouse with respect to the outside. This value can be considered low as compared to the behavior of naturally ventilated greenhouses.
\end{abstract}

\section{INTRODUCTION}

In the Latin America and Caribbean region, emerging countries with a great diversity of geographical and agroclimatic zones exist. In countries such as Panama, there are factors that generate great concern among stakeholders in the agricultural sector, one of which is the vulnerability of subsistence agricultural systems to the adverse effects of climate change. This has a negative effect on the food security of the current population, an effect that will be even more critical for the future population levels $[1,2]$.

Currently, the agricultural sector in Panama faces important issues, such as the lack of labor. In the last three decades, the agricultural sector has shrined by approximately 50\%, decreasing the food availability for $25 \%$ of the population [3]. On the other hand, the effects of climate change and variability phenomena such as El Niño-Southern Oscillation (ENSO) have caused severe drought seasons that, together with the deterioration of farmland, have restricted agricultural production $[4,5]$. Faced with these problems, the government has promoted protected cropping and vertical agriculture as strategies to intensify agricultural production. However, many of these production systems have been developed for highland regions where cold climates predominate. Some of these have failed because the technological solutions have not been adapted to the specific conditions of the country [3].

During the last decade, insect-proof screenhouses (IP-SH) have gained a lot of interest among growers. These simple and cheap structures offer advantages such as the protection of the crops against pests, reduction of excessive solar radiation levels and, a higher water efficiency use which is relevant in drought prone warm regions [6-11].

One of the factors that must be analyzed before the implementation of an IP-SH is the thermal behavior within the structure due to the airflow reduction caused by the porous screen $[12,13]$. Computational fluid dynamics (CFD) is a widely used technique to study air flows and the spatial distribution of variables such as temperature inside protected agriculture structures. Through this technique, fast and accurate results can be obtained under different simulation scenarios $[14,15]$.

The use of CFD in microclimate studies for agricultural production structures dates back to the work of Okushima et al. [16], who performed the first approximation by numerical simulation of air flows in a greenhouse previously analyzed using a wind tunnel. The first numerical results reported did not show a good agreement with the experimental results mainly due to the computational limitations to generate and optimal numerical grid.

In a later work, with greater computational power and a better understanding of the natural ventilation phenomenon with in greenhouses, Mistriotis et al. [17, 18] developed 2D and 3D studies for Mediterranean greenhouses. They reported airflows in the leeward side with a direction opposite to that of the external wind, a behavior that was in agreement with the experimental results. Numerical studies were also developed to analyze the thermal component of natural ventilation using the Boussinesq approximation, which is a model that describes the buoyancy phenomenon generated by the increase in air temperature due to the density change [19].

During the first decade of the XXI century, these previous results allowed the development of multiple works related to natural ventilation for different greenhouse types in countries such as Spain, France, Greece, Morocco and Mexico. The results of these studies can be reviewed in the work of Bournet and Boulard [20]. In the same way, CFD studies applied to screenhouses started to emerge, where the main works were focused on the study of the thermal and aerodynamic behavior 
of the flat roof screenhouse structure $[21,22]$. This studies that determined that the shape of the side wall of the structure differentially affects the air flows from the outside environment. Likewise, in this type of studies it was possible to identify that within this type of structures, thermal inversion phenomena occur during the night time; therefore, the inside air has a lower temperature with respect to the outside environment [23].

The air flow velocity inside a screenhouse will depend on the structure and the pore diameter of the porous screen; therefore, it is a factor that must be analyzed when selecting the type of screen to be used as covering [24, 25]. On the other hand, Flores-Velazquez et al. [26] in a CFD study developed in Mexico concluded that the shape of the screenhouse roof directly influences the air flow rates moving through the region where the crops are grown. However, the authors concluded that further studies on this aspect should be carried out. Follow up studies such as a 2D one by Villagrán [27] and a 3D one by Villagrán and Jaramillo [28] determined that an asymmetrical roof screenhouse was able to induce greater air flows at the cultivation area, generating a lower thermal gradient, benefiting the crop growth.

Currently, there are no CFD studies applied to this area of knowledge developed in Panama. However, at the regional level, in the last three years there has been some research carried out in Costa Rica [29], Colombia [28] and Dominican Republic [30]. Such studies allowed to optimize the microclimatic behavior in screenhouses structures established in warm climate regions. The aim of this research was to evaluate through a 3D CFD model, the spatial behavior of temperature and air flows inside a proposed IP-SH to be built in the Pacific coastal region of Panama.

\section{MATERIALS AND METHODS}

\subsection{Description of IP-SH}

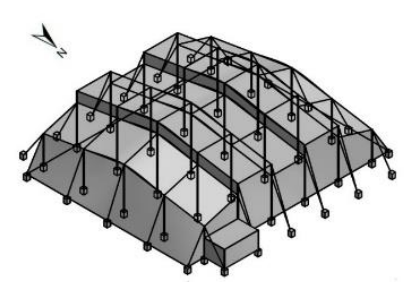

(a) Isometric view

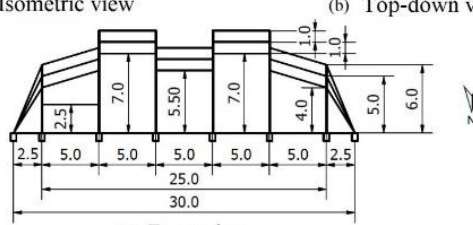

(c) Front view

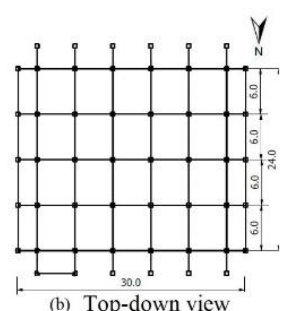

$Y$
Figure 1. Geometric scheme of the IP-SH, (a) Isometric view, (b) Top-down view and (c) Front view

The development of the numerical simulations was carried out for a virtual model of the IP-SH. The shape of the roof shows a variation in its height and the covered floor area was $720 \mathrm{~m}^{2}$ (Figure 1). The IP-SH is proposed to be built in the El Ejido Experimental Station of the Institute of Agricultural Research of Panama - IDIAP, located in Los Santos Province, Panama. The IP-SH has a cross section (x-axis) of $30 \mathrm{~m}$ and a longitudinal section (z-axis) of $24 \mathrm{~m}$. The minimum height of IP-SH is $4.0 \mathrm{~m}$ on the sides and has a maximum height of 9.0 $\mathrm{m}$ on the deck above the middle section. The side walls and roof were covered with a semi-transparent insect proof screen with a thread count of $16.1 \times 10.1 \mathrm{~cm}^{-2}$ and a porosity $(\varepsilon)$ of 0.33 .

\subsection{CFD model}

CFD is a technique for solving a non-linear set of partial differential equations known as Navier-Stokes equations. These equations are discretized to linear equations through numerical solving methods. The CFD methodology allows the calculation of air flow patterns and thermal distribution patterns generated inside a protected agricultural structure. The phenomena of transport by free convection can be described by Eq. (1). This is the general transport equation for a fluid in a three-dimensional field and in a steady state.

$$
\frac{\partial\left(u_{\emptyset}\right)}{\partial x}+\frac{\partial\left(v_{\varnothing}\right)}{\partial y}+\frac{\partial\left(w_{\varnothing}\right)}{\partial z}=\Gamma \nabla^{2} \emptyset+S_{\varnothing}
$$

where, $\mathrm{u}, \mathrm{v}$ and $\mathrm{w}$ are the components of the velocity vector, $\mathrm{x}$, $\mathrm{y}$ and $\mathrm{z}$ represent the coordinates in Cartesian space, $\nabla^{2}$ is the Laplacian operator, $\Gamma$ is the diffusion coefficient, $\emptyset$ represents the concentration of the quantity transported in a dimensional form (Moment, mass and energy) and, $S_{\varnothing}$ is the source term.

The airflow modeled considered turbulence through the standard $k-\varepsilon$ model. This is a semi-empirical model based on the transport equations that solve the kinetic turbulent energy $\varepsilon$ and the dissipation of this energy per unit volume $\varepsilon$. The $k$ $\varepsilon$ has been the most applied and widely validated model in greenhouse and screenhouse airflow studies showing to be computationally efficient while providing realistic solutions $[14,31]$. Boussinesq's model was considered in order to simulate variations in air density inside the screenhouse generated by temperature changes. The side and front surfaces and the roof of the IP-SH were modeled as porous media. This was done by using equations derived from the flow of a free and forced fluid through porous materials, taking into account their porosity and permeability properties [32]. These equations can be derived using Eq. (2). which describes the Darcy-Forcheimer law.

$$
\frac{\partial p}{\partial x}=\frac{\mu}{K} u+\rho \frac{C f}{\sqrt{K}} u|u|
$$

where, $\mathrm{u}$ is the velocity of air $\left(\mathrm{m} \mathrm{s}^{-1}\right) ; \mu$ is the dynamic viscosity of the fluid $\left(\mathrm{kg} \mathrm{m}^{-1} \mathrm{~s}^{-1}\right), \mathrm{K}$ is the permeability of the porous medium $\left(\mathrm{m}^{2}\right) ; C f$ is the inertial factor of the screen; $\rho$ is the air density $\left(\mathrm{kg} \mathrm{m}^{-3}\right)$, and $\partial \mathrm{x}$ is the thickness of the porous material (m). The radiation model selected was the discrete ordinate (DO) model with angular discretization. This model has been widely used in the study of protected agriculture and allows the calculation of radiation and convective exchanges occurring in the computational domain [33-37]. The DO model is described by Eq. (3).

$$
\begin{aligned}
& \nabla \cdot\left(I_{\lambda}(\underset{r}{\underset{s}{\Rightarrow}} \underset{s}{\Rightarrow}) \underset{s}{\Rightarrow}\right)+\left(a_{\lambda}+\sigma_{s}\right) I_{\lambda}(\underset{r}{\underset{s}{\Rightarrow}}) \\
& =a_{\lambda} n^{2} \frac{\sigma T^{4}}{\pi}
\end{aligned}
$$

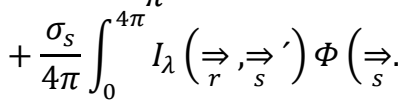

$$
\begin{aligned}
& \left.\underset{s}{\Rightarrow^{\prime}}\right) d \Omega^{\prime}
\end{aligned}
$$


where, $I_{\lambda}$ is the intensity of radiation at a wavelength; $\underset{r}{\underset{s}{,} \Rightarrow}$ are the vectors that indicate the position and direction, respectively; $\underset{s}{\Rightarrow}$ 'is the scattering direction vector; $\sigma_{s}, a_{\lambda}$ are the coefficients of dispersion and spectral absorption; $n$ is the index of refraction; $\nabla$ is the divergence operator; $\sigma$ is StefanBoltzmann's constant $\left(5.669 \times 10^{-8} \mathrm{Wm}^{-2} \mathrm{~K}^{-4}\right), \Phi, \mathrm{T}$ y $\Omega$ are the phase function, the local temperature $\left({ }^{\circ} \mathrm{K}\right)$ and the solid angle, respectively.

Likewise, in order to simplify the resolution of the 3D CFD model, no type of crop was included. This was done in order to speed up the numerical calculation and establish the behavior of the air flow and temperature under the worst possible scenario. Under this scenario much of the radiation incident on the interior of the IP-SH is converted into heat generating a temperature increase. To solve the pressuremomentum coupled equations, a semi-implicit solution method was adopted for the pressure-linked equations through a second-order discretization scheme for momentum, energy and turbulence. The convergence criteria for these variables were set at $10^{-6}$

\subsection{Numerical mesh, boundary conditions and initial conditions implemented in the simulations}

For the development of the simulations a large computational domain was created including the IP-SH and its boundaries (Figure 2). The dimensions of the computational domain in each of the axes (x-y-z) were 330,70 and $320 \mathrm{~m}$, respectively. These were established according to the recommendations reported for wind and natural ventilation studies of buildings that used the numerical simulation technique such as those developed by Perén et al. [38] and Kim et al. [39]. In the process of generating and testing the independence of the solution to the size of the numerical grid, an unstructured grid of square elements was selected with a total of 14,171,713 volumes. This size was defined after 9 different grid sizes were evaluated that contained a finite number of elements within the range $[1,623,865-21,293,965]$. The process of selecting the appropriate size was carried out in accordance with $\mathrm{He}$ et al. [40] and successfully applied by Villagrán et al. [14]. The evaluation of the quality of the numerical grid was carried out by means of the $3 \times 3$ relative determinant calculation, which showed a behavior higher than $96.4 \%$ with cells between 0.95 and 1 which indicated perfectly regular grid elements [41].

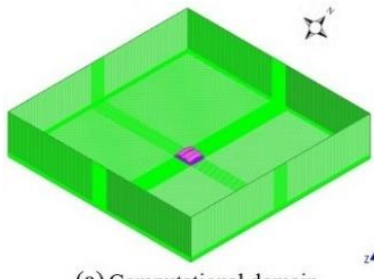

(a) Computational domain

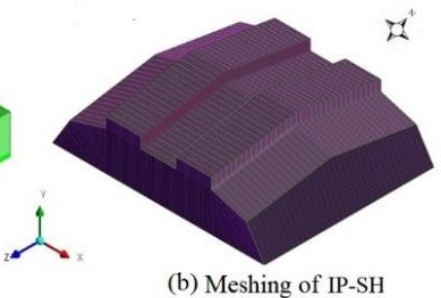

(b) Meshing of IP-SH
Figure 2. (a) Computational domain and (b) detail of the numerical grid of IP-SH

The following boundary conditions were established for the computational domain: symmetric for the upper region, pressure outlet for the side where the simulated airflow exits, wall for the floor region, porous medium for the roof and walls of the structure, and the limit where the airflow enters was established as the entry limit, establishing for this entry limit a logarithmic vertical velocity distribution profile as proposed by Khaoua et al. [42] and making adjustments according to the characteristics of the study region. Therefore, the air inlet and outlet limits were defined according to the prevailing outside wind direction for each of the months evaluated, as shown in Table 3 .

The physical and optical properties of the materials (Table 1) and the aerodynamic properties of the insect-proof porous screen (Table 2) used in the simulation were taken from the studies of Flores-Velazquez et al. [43] and Reynafarje et al. [44].

The initial simulation conditions established were obtained from the historical climate information available for the region of study since 1987. In accordance with the purpose of this research, it was determined to analyze the behavior of the structure on a monthly basis. The solar radiation and maximum average temperature variables were used as extreme conditions, coupled with the average speed of the exterior air and its dominant direction were used. Therefore, a total of 12 simulations were carried out (Table 3 ).

Table 1. Properties of materials used in the CFD simulation

\begin{tabular}{cccc}
\hline \multicolumn{4}{c}{ Physical and optical properties of the materials used } \\
\hline & Air & Ground & Screen \\
Density $\left(\rho, \mathrm{kg} \mathrm{m}^{-3}\right)$ & 1.225 & 1,400 & 990 \\
Thermal conductivity $\left(\mathrm{k}, ~ W ~ m^{-1} \mathrm{~K}^{-1}\right)$ & 0.0242 & 1.5 & 0.33 \\
Specific heat $\left(\mathrm{Cp}, \mathrm{J} \mathrm{K}^{-1} \mathrm{~kg}^{-1}\right)$ & $1,006.43$ & 1,738 & 1,900 \\
Coefficient of thermal expansion & 0.0033 & & \\
$\left(\mathrm{~K}^{-1}\right)$ & 0.19 & 0.9 & 0.2 \\
Absorptivity & 0 & -10 & 0 \\
Scattering coefficient & 1 & 1.92 & 0.05 \\
Refractive index & 0.9 & 0.95 & 0.45 \\
Emissivity & & & \\
\hline
\end{tabular}

Table 2. Aerodynamic properties of the insect-proof porous screen

\begin{tabular}{|c|c|c|c|}
\hline \multicolumn{4}{|c|}{ Aerodynamic properties of porous insect-proof screen } \\
\hline Type of porous screen & $\begin{array}{l}\text { Porosity } \\
(\varepsilon)\end{array}$ & $\begin{array}{c}\text { Effect Viscosity } \\
(\alpha)\end{array}$ & $\mathrm{C}_{2}$ \\
\hline $\begin{array}{c}16.1 * 10.2 \text { or threads for } \\
\mathrm{cm}^{2}\end{array}$ & 0.33 & $3.98 \mathrm{e}^{-09}$ & $\begin{array}{c}1918 \\
5\end{array}$ \\
\hline
\end{tabular}

Table 3. Initial conditions for each simulation scenario

\begin{tabular}{|c|c|c|c|c|}
\hline $\begin{array}{c}\text { Scenario } \\
\text { Month }\end{array}$ & $\begin{array}{c}\text { Temperature } \\
\left({ }^{\circ} \mathrm{C}\right)\end{array}$ & 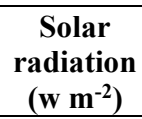 & $\begin{array}{l}\text { Wind } \\
\text { speed } \\
\left(\mathrm{m} \mathrm{s}^{-1}\right) \\
\end{array}$ & $\begin{array}{c}\text { Wind } \\
\text { direction }\end{array}$ \\
\hline S01- January & 33.7 & 897.1 & 3.4 & $\mathrm{~N}$ \\
\hline $\begin{array}{c}\text { S02- } \\
\text { February }\end{array}$ & 34.2 & 913.5 & 3.5 & $\mathrm{~N}$ \\
\hline S03-March & 34.9 & 965.9 & 3.5 & $\mathrm{~N}$ \\
\hline S04- April & 35.7 & 976.2 & 3.1 & $\mathrm{~N}$ \\
\hline S05-May & 35.7 & 973.4 & 2.2 & W \\
\hline S06-June & 34.6 & 921.1 & 1.6 & $\mathrm{~N}$ \\
\hline S07- July & 34.2 & 867.6 & 1.4 & W \\
\hline S08-August & 34.4 & 898.1 & 1.2 & W \\
\hline $\begin{array}{c}\text { S09- } \\
\text { September }\end{array}$ & 34.3 & 878.7 & 1.1 & $\mathrm{~W}$ \\
\hline $\begin{array}{c}\text { S10- } \\
\text { October }\end{array}$ & 33.8 & 848.5 & 1.1 & W \\
\hline $\begin{array}{c}\text { S11- } \\
\text { November }\end{array}$ & 33.4 & 827.5 & 1.4 & W \\
\hline $\begin{array}{c}\mathrm{S} 12- \\
\text { December }\end{array}$ & 33.3 & 811.9 & 2.4 & $\mathrm{~N}$ \\
\hline
\end{tabular}




\section{RESULTS AND DISCUSSION}

\subsection{Model validation}

The numerical model used in this work was previously validated for a screenhouse structure built in the Colombian Caribbean region at the Caribbean Research Center of the Colombian Agricultural Research Corporation AGROSAVIA. Within this screenhouse, 5 temperature sensors recorded hourly data during 35 days. The validation of the numerical model was carried out by comparing experimental and simulated data through goodness-of-fit criteria such as the mean absolute error (MAE) and the root mean square error (RMSE), performing a calculation process similar to that reported by Villagrán and Bojacá [45]. The results showed low values of MAE and RMSE that allow us to deduce that the predictions made by the CFD model are satisfactory (Table 4).

This type of validation where the data was collected under the similar initial climatic conditions of those used in the simulation has been one of the validation methods successfully applied in CFD studies for natural ventilation of agricultural structures $[46,47]$. It is also important to mention that finding settings such as the ones reported in this research for temperature, allowed to reliably analyze the behavior of the air flow inside the structure. The above due to the dynamics of the thermal behavior inside the screenhouse will be directly related to the conditions of air flow velocity and direction since other factors such as the level of solar radiation and the properties of the soil and roofing materials are already defined in the starting conditions of the CFD model [48].

Table 4. Results of goodness-of-fit parameters obtained in the validation of the CFD model

\begin{tabular}{lcc}
\hline & MAE $\left({ }^{\circ} \mathbf{C}\right)$ & RMSE $\left({ }^{\circ} \mathbf{C}\right)$ \\
\hline Sensor 1 & 0.42 & 0.52 \\
Sensor 2 & 0.36 & 0.44 \\
Sensor 3 & 0.30 & 0.36 \\
Sensor 4 & 0.22 & 0.27 \\
Sensor 5 & 0.23 & 0.29 \\
\hline
\end{tabular}

\subsection{Air flow patterns}

The results allowed to determine the qualitative characteristics of the airflow pattern inside the IP-SH, which are influenced by the speed and dominant wind direction of the external environment for each of the simulated conditions (Figure 3). In this case, the behavior for the simulations S01 and $\mathrm{S} 03$, which is repeated in the cases $\mathrm{S} 02, \mathrm{~S} 04, \mathrm{~S} 06$ and S12 where the incident wind comes from the North $(\mathrm{N})$, showed a pattern of air flow impacts on the windward facade and enters the structure, to later be directed horizontally through the $\mathrm{Z}$ axis, until it leaves the IP-SH through the leeward facade. In the figures corresponding to these simulations, the air flow developed inside the IP-SH was characterized by a loss of speed as it moves along the $\mathrm{Z}$ axis. It was also possible to observe air flow vectors near the leeward side of the building that showed a greater deceleration with respect to the general flow, vectors that additionally are directed vertically to the roof area

In the case of scenarios S05 and S07 to S11, where the outside wind comes from the west (W), it is observed that the air flow impacts on the windward side, part of this flow enters the interior of the IP-SH and, the rest moves to the outside following the geometric shape of the roof of the structure. The air flow that enters the structure and directed in the longitudinal direction of the $\mathrm{X}$ axis, showed vectors of greater velocity in the zones neighboring the facades, while in the central zone the air flow slows down as it approaches the leeward side.
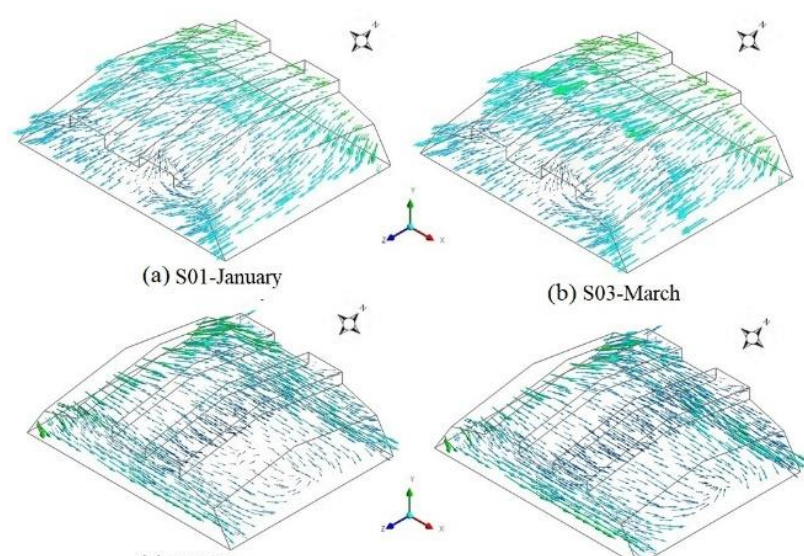

(b) S03-March

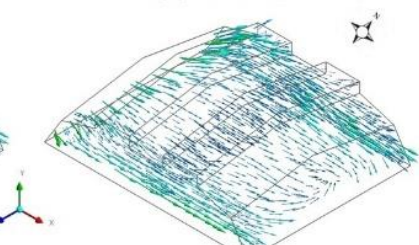

(d) S07-July

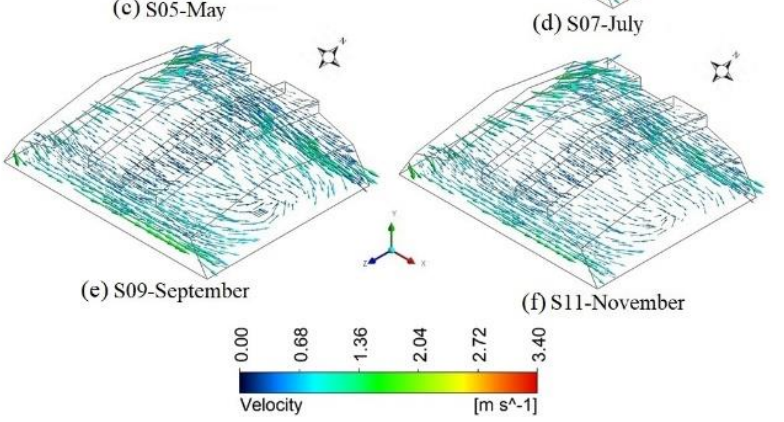

Figure 3. Simulated airflow patterns for IP-SH (a) S01January, (b) S03- March, (c) S05- May, (d) S07-July, (e) S09- September and (f) S11- November

Finally, this airflow near the leeward side and over the central zone of the IP-SH, generates a low velocity convective movement cell, which can generate higher temperature conditions over this region. It is worth mentioning that the qualitative characteristics of the air flow patterns discussed in this section are influenced by the loss of impulse presented on the air flow due to the presence of the anti-insect screen. Likewise, the flow pattern inside the IP-SH is driven by the wind and thermal components of natural ventilation, this type of results has already been discussed and verified in similar works such as those developed by Flores-Velázquez \& Montero [10] and Villagrán \& Rodriguez [31]. Results that have been experimentally validated as reported by Teitel et al. $[8,49]$.

To determine the quantitative behavior, air velocity data were extracted on the mid-section of the structure along the $\mathrm{X}$ and $\mathrm{Z}$ axes at a height of $1.7 \mathrm{~m}$ above ground level, since this is the region of the air volume that frequently interacts with the area where the crops are established. For each set of data obtained in each axis, parameters such as the mean velocity $\left(V_{\text {in }}\right)$ and the normalized velocity $\left(\mathrm{V}_{\text {nor }}=\right.$ Air velocity inside $/$ Air velocity outside) were calculated for each parameter with its respective standard deviation (Table 5).

The results showed a behavior where for the $X$ axis the $V_{\text {in }}$ presented values between $0.26 \pm 0.11 \mathrm{~ms}^{-1}$ and $0.73 \pm 0.10 \mathrm{~m}$ $\mathrm{s}^{-1}$, which represents reductions of air flow with respect to the outside of $76.1 \%$ and $78.9 \%$ respectively, while for the case of the $\mathrm{Z}$ axis, the $\mathrm{V}_{\text {in }}$ values were within the range of $0.31 \pm 0.10$ 
$\mathrm{m} \mathrm{s}^{-1}$ and $0.70 \pm 0.31 \mathrm{~m} \mathrm{~s}^{-1}$, which is equivalent to air flow reductions of $80.6 \%$ and $79.2 \%$. These results coincide with those reported in the literature for air flow studies in this type of structure such as those of Flores-Velazquez et al. [43] and
Flores-Velazquez and Montero [10]. Additionally, inside air velocities are within the recommended values $\left(0.5-0.7 \mathrm{~m} \mathrm{~s}^{-1}\right)$ for plant growth and development within protected agricultural structures [50].

Table 5. Airflow pattern parameters obtained from CFD simulation

\begin{tabular}{cccccc}
\hline \multicolumn{5}{c}{ X-axis } \\
\hline Scenario & $\mathrm{V}_{\text {in }}\left(\mathrm{ms}^{-1}\right)$ & $\mathrm{V}_{\text {nor }}(\%)$ & Scenario & $\mathrm{V}_{\text {in }}\left(\mathrm{ms}^{-1}\right)$ & $\mathrm{V}_{\text {nor }}(\%)$ \\
\hline S01- January & $0.69 \pm 0.29$ & $20.4 \pm 2.93$ & S07- July & $0.27 \pm 0.07$ & $19.4 \pm 4.78$ \\
S02- February & $0.71 \pm 0.11$ & $20.6 \pm 2.91$ & S08- August & $0.27 \pm 0.08$ & $22.3 \pm 4.31$ \\
S03- March & $0.73 \pm 0.10$ & $21.1 \pm 2.93$ & S09- September & $0.26 \pm 0.11$ & $23.9 \pm 4.29$ \\
S04- April & $0.65 \pm 0.09$ & $21.2 \pm 3.11$ & S10- October & $0.28 \pm 0.07$ & $25.1 \pm 4.28$ \\
S05- May & $0.31 \pm 0.13$ & $15.2 \pm 6.29$ & S11- November & $0.30 \pm 0.12$ & $22.1 \pm 4.85$ \\
S06- June & $0.38 \pm 0.08$ & $24.1 \pm 5.44$ & S12- December & $0.53 \pm 0.14$ & $22.2 \pm 3.54$ \\
\hline \multicolumn{7}{c}{ Z-Axis } \\
\hline Scenario & $\mathrm{V}_{\text {in }}\left(\mathrm{ms}^{-1}\right)$ & $\mathrm{V}_{\text {nor }}(\%)$ & Scenario & $\mathrm{V}_{\text {in }}\left(\mathrm{ms}^{-1}\right)$ & $\mathrm{V}_{\text {nor }}(\%)$ \\
\hline S01- January & $0.65 \pm 0.29$ & $19.1 \pm 8.57$ & S07- July & $0.38 \pm 0.15$ & $27.7 \pm 9.93$ \\
S02- February & $0.66 \pm 0.31$ & $18.9 \pm 9.03$ & S08- August & $0.37 \pm 0.14$ & $31.4 \pm 10.4$ \\
S03- March & $0.70 \pm 0.31$ & $20.2 \pm 8.71$ & S09- September & $0.37 \pm 0.12$ & $33.7 \pm 10.4$ \\
S04- April & $0.60 \pm 0.27$ & $19.4 \pm 8.96$ & S10- October & $0.38 \pm 0.14$ & $34.8 \pm 10.6$ \\
S05- May & $0.44 \pm 0.17$ & $21.2 \pm 8.19$ & S11- November & $0.40 \pm 0.19$ & $30.1 \pm 10.5$ \\
S06- June & $0.31 \pm 0.10$ & $19.4 \pm 6.05$ & S12- December & $0.46 \pm 0.22$ & $18.6 \pm 8.00$ \\
\hline
\end{tabular}

Table 6. Thermal behavior parameters obtained from CFD simulation

\begin{tabular}{cccccc}
\hline \multicolumn{7}{c}{$\mathbf{X}$-axis } \\
\hline Scenario & $\operatorname{Tin}\left({ }^{\circ} \mathrm{C}\right)$ & $\Delta \mathrm{T}_{\mathrm{m}}\left({ }^{\circ} \mathrm{C}\right)$ & Scenario & $\operatorname{Tin}\left({ }^{\circ} \mathrm{C}\right)$ & $\Delta \mathrm{T}_{\mathrm{m}}\left({ }^{\circ} \mathrm{C}\right)$ \\
\hline S01- January & $33.9 \pm 0.06$ & $0.14 \pm 0.06$ & S07- July & $35.3 \pm 0.67$ & $1.11 \pm 0.67$ \\
S02- February & $34.4 \pm 0.03$ & $0.15 \pm 0.03$ & S08- August & $35.6 \pm 0.75$ & $1.12 \pm 0.75$ \\
S03- March & $35.1 \pm 0.02$ & $0.14 \pm 0.02$ & S09- September & $35.5 \pm 0.80$ & $1.20 \pm 0.80$ \\
S04- April & $35.9 \pm 0.03$ & $0.17 \pm 0.03$ & S10- October & $35.1 \pm 0.89$ & $1.32 \pm 0.89$ \\
S05- May & $36.8 \pm 0.84$ & $1.10 \pm 0.84$ & S11- November & $34.6 \pm 0.77$ & $1.23 \pm 0.77$ \\
S06- June & $35.7 \pm 0.07$ & $0.70 \pm 0.07$ & S12- December & $33.8 \pm 0.08$ & $0.49 \pm 0.08$ \\
\hline \multicolumn{7}{c}{ Z-axis } \\
\hline Scenario & $\operatorname{Tin}\left({ }^{\circ} \mathrm{C}\right)$ & $\Delta \mathrm{T}_{\mathrm{m}}\left({ }^{\circ} \mathrm{C}\right)$ & Scenario & Tin $\left({ }^{\circ} \mathrm{C}\right)$ & $\Delta \mathrm{T}_{\mathrm{m}}\left({ }^{\circ} \mathrm{C}\right)$ \\
\hline S01- January & $34.2 \pm 0.54$ & $0.42 \pm 0.54$ & S07- July & $35.0 \pm 0.17$ & $0.82 \pm 0.17$ \\
S02- February & $34.7 \pm 0.69$ & $0.51 \pm 0.69$ & S08- August & $35.3 \pm 0.16$ & $0.85 \pm 0.16$ \\
S03- March & $35.3 \pm 0.55$ & $0.43 \pm 0.55$ & S09- September & $35.2 \pm 0.12$ & $0.87 \pm 0.12$ \\
S04- April & $36.2 \pm 0.62$ & $0.49 \pm 0.62$ & S10- October & $34.7 \pm 0.21$ & $0.92 \pm 0.21$ \\
S05- May & $36.6 \pm 0.12$ & $0.85 \pm 0.12$ & S11- November & $34.3 \pm 0.18$ & $0.89 \pm 0.18$ \\
S06- June & $35.7 \pm 1.04$ & $1.15 \pm 1.04$ & S12- December & $34.2 \pm 1.00$ & $0.89 \pm 1.00$ \\
\hline
\end{tabular}

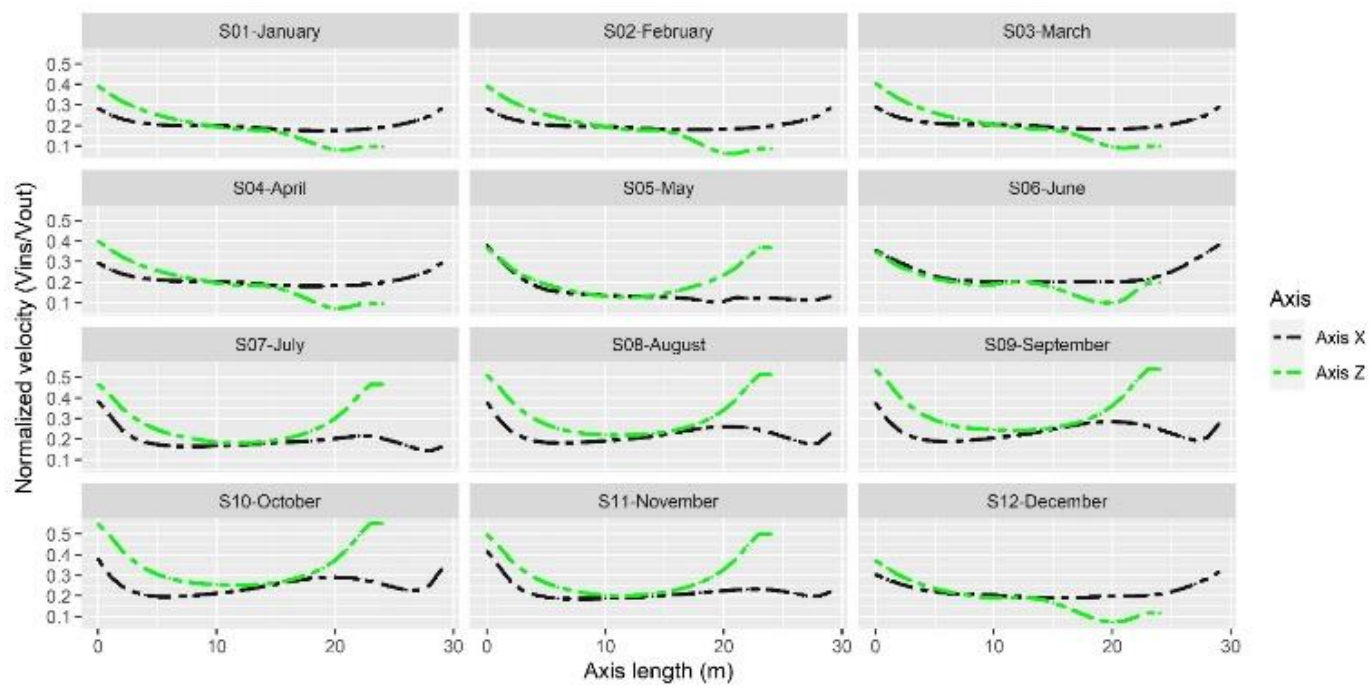

Figure 4. Normalized velocity behavior in IP-SH

The spatial behavior for $V_{\text {nor }}$ in each of the axes was calculated for each meter of the $\mathrm{X}$ and $\mathrm{Z}$ axes length. We found that there is an airflow over the windward side or facade with a lower speed value between 50 and $60 \%$ with respect to the incident wind speed (Figure 4). Once the flow enters the structure and, depending on the longitudinal direction in which 
it moves, there is a loss of velocity up to $90 \%$ lower than the speed of the outside wind near the leeward sides or facades. Also in this Figure 4, it can be observed how on the axis perpendicular to the flow of external air the highest speeds are presented near the edges of the structure. As already mentioned in the qualitative description, on this axis the vectors slow down towards the central zone of the structure. The highest velocity on the sides is generated by the strong interaction that there is near the surface of the porous screen with the air flow of the outside environment [51].

\subsection{Spatial temperature distribution}

One of the consequences on the microclimate generated by the restriction of air flow, is the increase in air temperature inside the screenhouse. This, in turn, must also be analyzed through the spatial behavior of this variable and its distribution in terms of magnitude, since excessive thermal gradients in the longitudinal, transverse or vertical can generate effects on the growth and development of crops [52, 53]. The results obtained for each of the simulations allowed us to analyze these behaviors (Figure 5).

In spatial terms, it can be seen how the highest temperature values for each simulation were obtained in areas where air flows have a low velocity behavior (Figure 3 ). This coincides with most studies on natural ventilation in protected agricultural structures. The temperature behavior is related to the speed of the airflow pattern; therefore, zones of higher speed are in turn the zones of lower temperature and vice versa $[45,54,55]$.

Qualitatively, it can be observed that the scenario with the highest temperature and spatial heterogeneity occurred for the month of May, which is directly related to the ambient temperature, the level of solar radiation and the wind speed and direction. In this case, it can be observed how the heat patch is located on the leeward side just over the area where the low speed convective cell is generated. This prevents the renewal of air in that region, consequently increasing the temperature. This same behavior with a lower degree of intensity was observed for the July and September. On the contrary, for January, March and November we observed behaviors with a more homogeneous spatial distribution.

For the quantitative analysis, as well as for the air flow patterns, the average temperature inside the structure $\left(T_{i n}\right)$ and the mean thermal differential were determined $\left(\Delta \mathrm{T}_{\mathrm{m}=} \mathrm{T}_{\text {inside- }}\right.$ $\mathrm{T}_{\text {outside }}$ ) for both the $\mathrm{X}$ and $\mathrm{Z}$ axes. The $\mathrm{T}_{\text {in }}$ on the $\mathrm{X}$ axis, were within the range of $33.8 \pm 0.08^{\circ} \mathrm{C}$ and $36.8 \pm 0.84^{\circ} \mathrm{C}$, while for the $\mathrm{Z}$ axis the $\mathrm{T}_{\text {in }}$ variation was within the range of $34.2 \pm$ $1.00^{\circ} \mathrm{C}$ and $36.6 \pm 0.12^{\circ} \mathrm{C}$ (Table 6).

On the other hand, the $\Delta \mathrm{T}_{\mathrm{m}}$ showed a variation between 0.14 $\pm 0.06^{\circ} \mathrm{C}$ and $1.32 \pm 0.89^{\circ} \mathrm{C}$ for the $\mathrm{X}$ axis and, between 0.42 $\pm 0.54^{\circ} \mathrm{C}$ and $1.15 \pm 1.04^{\circ} \mathrm{C}$ for the $\mathrm{Z}$ axis. The $\Delta \mathrm{T}_{\mathrm{m}}$ obtained in this study were lower than those reported in the study developed by Tanny et al. [56] where $\Delta \mathrm{T}_{\mathrm{m}}$ was between 1.5 and $2.5^{\circ} \mathrm{C}$ and were also lower than those reported by FloresVelazquez et al. [43] who reported $\Delta \mathrm{T}_{\mathrm{m}}$ until $3.2^{\circ} \mathrm{C}$ for outside wind speeds of $2 \mathrm{~m} \mathrm{~s}^{-1}$.

These previous works were developed on screenhouses using porous insect-proof screen and under climatic conditions similar to those of this research. However, it is possible to infer that differential factor of this study such as the shape of the roof and the average heights allowed to substantially improve the thermal behavior by decreasing the thermal gradients between the interior and exterior environment.

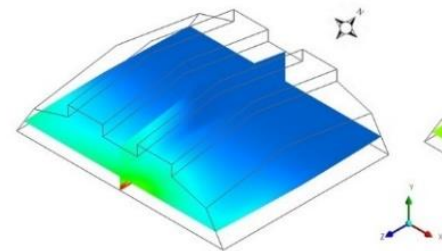

(a) S01-January

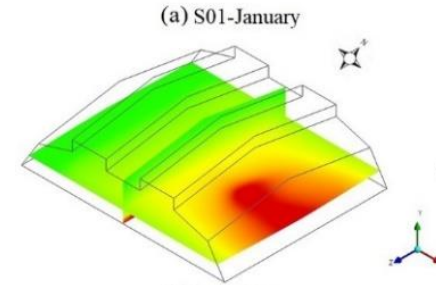

(c) S05-May

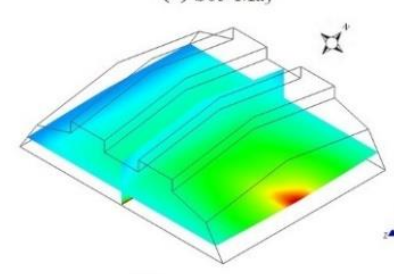

(e) S09-September

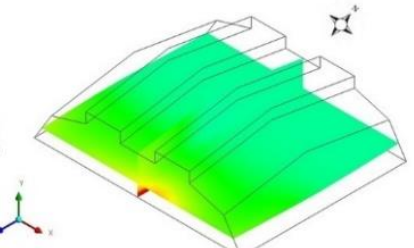

(b) S03-March

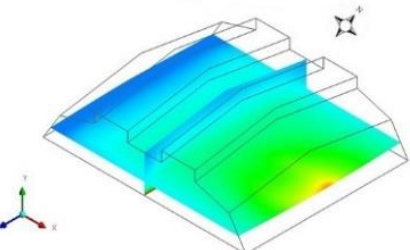

(d) S07-July

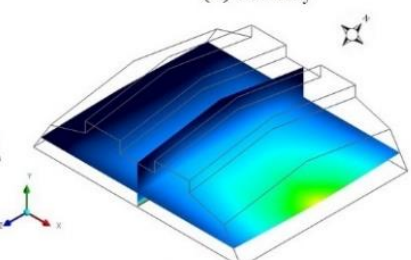

(f) S11-November

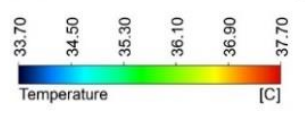

Figure 5. Simulated spatial temperature distribution for IPSH, (a) S01- January, (b) S03- March, (c) S05- May, (d) S07July, (e) S09- September and (f) S11- November

The behavior of the thermal differential across the $\mathrm{X}$ and $\mathrm{Z}$ axes showed a spatial distribution that can be considered homogeneous for the months where the external wind speed is higher than $3 \mathrm{~m} \mathrm{~s}^{-1}$, as is the case for scenarios S01 to S04. For these conditions the $\Delta \mathrm{T}$ was $\leq 2^{\circ} \mathrm{C}$ (Figure 6), value that can be considered as the maximum limit in terms of microclimatic uniformity for $\Delta \mathrm{T}$ that should be generated between the coldest and hottest point inside protected agricultural structures [57]. It can also be seen that for the remaining scenarios $\Delta \mathrm{T}$ does not exceed $3^{\circ} \mathrm{C}$; therefore, as mentioned above, the behavior of the structure will be very dependent on the ventilation rates generated by the air flows as a function of the air speed of the outside environment [43]. Once the crops are established, in order to improve the economy or guarantee food security, the thermal differentials should be lower since phenomena such as crop evapotranspiration and the presence of plants will influence the energy balance within the IP-SH, as demonstrated by the study of $\mathrm{Xu}$ et al. [58].

To conclude the analysis, the implementation of a screenhouse structure without any type of equipment for climate control is an alternative that would allow farmers in the low and warm lands of Panama to have some degree of microclimate management for the production of fruit and vegetables under cover. The behavior of the IP-SH under high temperature and radiation conditions did not exceed the maximum tolerable limit for most crops grown in warm regions, which is set at $40^{\circ} \mathrm{C}$ with recommended values preferably between 25 and $35^{\circ} \mathrm{C}$, this in order to ensure adequate plant growth and development [59-61]. Therefore, this cultivation technique can help boost agricultural production in Panama, which will positively impact the dynamics of food production, helping to improve the food security indices in both the short and medium term under a sustainable intensive cultivation model. This study can be used 


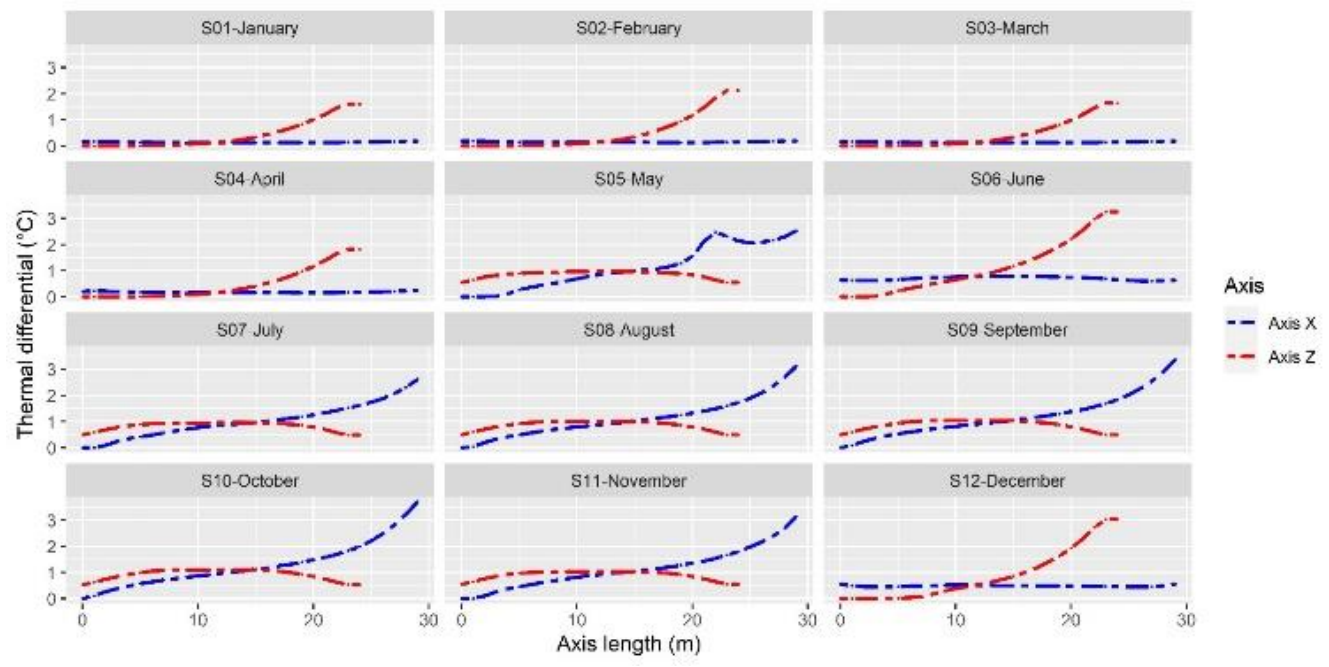

Figure 6. Behavior of the thermal differential inside IP-SH

\section{CONCLUSIONS}

The implementation of screenhouse structures as a strategy to intensify horticultural production is an alternative that should be explored and optimized in Latin American and Caribbean countries. In this research, it was found that the use of screenhouse affects the air flow patterns inside the structure reducing the air movement speed inside the structure up to a value of $80 \%$ with respect to the air velocity outside. However, the thermal gradients between the inside and outside environment did not exceed average values of $2^{\circ} \mathrm{C}$ and presented a highly homogeneous behavior.

However, it should be noted that the screenhouse structure evaluated in this research has a greater height on the sides and in the central region and a geometry of the roof region made up of elements of different heights, as opposed to similar structures used in other parts of the world. This allowed to improve the behavior of the air flows and reduced the thermal gradients inside the screenhouse for the typical monthly climatic conditions that occur throughout the year in a warm climate region of Panama. Therefore, this structure could allow the establishment of horticultural crops throughout the year, which would help to improve the level of food security in this region.

\section{ACKNOWLEDGMENT}

The authors wish to thank the Colombian Agricultural Research Corporation - AGROSAVIA - and the Institute of Agricultural Research of Panama - IDIAP - for their technical and administrative support in this study. The research was funded by The Regional Fund of Agricultural Research and Technological Development - FONTAGRO - as part of the project "Innovations for horticulture in protected environments in tropical zones: an option for sustainable intensification of family farming in the context of climate change in LAC". The opinions expressed in this publication are solely those of the authors and do not necessarily reflect the views of FONTAGRO, its Board of Directors, the Bank, its sponsoring institutions, or the countries it represents.

\section{REFERENCES}

[1] Jat, M.L., Dagar, J.C., Sapkota, T.B., Govaerts, B., Ridaura, S.L., Saharawat, Y.S., Stirling, C. (2016). Climate change and agriculture: adaptation strategies and mitigation opportunities for food security in South Asia and Latin America. In Advances in agronomy, 137: 127235. https://doi.org/https://doi.org/10.1016/bs.agron.2015.12. 005

[2] Simon, X., Montero, M., Romero, O. (2020). Advancing food security through agroecological technologies: The implementation of the biointensive method in the dry corridor of Nicaragua. Sustainability, 12(3): 844. https://doi.org/10.3390/su12030844

[3] Collado, E., Fossatti, A., Saez, Y. (2018). Smart farming: A potential solution towards a modern and sustainable agriculture in Panama. AIMS Agriculture and Food, 4(2): 266-284. https://doi.org/ 10.3934/agrfood.2019.2.266

[4] Ordaz Díaz, J.L., Mora, J., Acosta, A., Serna Hidalgo, B., Ramírez, D. (2010). Belice: efectos del cambio climático sobre la agricultura. Naciones Unidas Comisión Económica para América Latina y el Caribe (CEPAL).

[5] Gameda, S., Loboguerrero, A.M., Boa, M., Martínez Barón, D., Martiz, G., Sierra, Y., Vanegas, L. (2014). Estado del arte en cambio climático, agricultura y seguridad alimentaria en Panamá.

[6] López-Martínez, A., Molina-Aiz, F.D., Valera, D.L., Espinoza-Ramos, K.E. (2020). Models for characterizing the aerodynamics of insect-proof screens from their geometric parameters. Biosystems Engineering, 192: 4255. https://doi.org/10.1016/j.biosystemseng.2020.01.013

[7] Ahemd, H.A., Al-Faraj, A.A., Abdel-Ghany, A.M. (2016). Shading greenhouses to improve the microclimate, energy and water saving in hot regions: A review. Scientia Horticulturae, 201: 36-45. https://doi.org/10.1016/j.scienta.2016.01.030

[8] Teitel, M., Garcia-Teruel, M., Ibanez, P.F., Tanny, J., Laufer, S., Levi, A., Antler, A. (2015). Airflow characteristics and patterns in screenhouses covered with fine-mesh screens with either roof or roof and side 
ventilation. Biosystems Engineering, 131: 1-14. https://doi.org/10.1016/j.biosystemseng.2014.12.01

[9] Teitel, M., Liang, H., Tanny, J., Garcia-Teruel, M., Levi, A., Ibanez, P.F., Alon, H. (2017). Effect of roof height on microclimate and plant characteristics in an insectproof screenhouse with impermeable sidewalls. Biosystems $\quad$ Engineering, 162: 11-19. https://doi.org/10.1016/j.biosystemseng.2017.07.001

[10] Flores-Velázquez, J., Montero, J.I. (2008). Computational fluid dynamics (CFD) study of large scale screenhouses. Acta Horticulturae, 797: 117-122. https://doi.org/10.17660/ActaHortic.2008.797.1

[11] Mahmood, A., Hu, Y., Tanny, J., Asante, E.A. (2018). Effects of shading and insect-proof screens on crop microclimate and production: A review of recent advances. Scientia Horticulturae, 241: 241-251. https://doi.org/10.1016/j.scienta.2018.06.078

[12] Perillo, A.C., Kucharik, C.J., Meehan, T.D., Serbin, S.P., Singh, A., Townsend, P.A., Gratton, C. (2015). Use of insect exclusion cages in soybean creates an altered microclimate and differential crop response. Agricultural and Forest Meteorology, 208: 50-61. https://doi.org/10.1016/j.agrformet.2015.04.014

[13] Liu, X., Xu, G., Wang, Q., Hang, Y. (2017). Effects of insect-proof net cultivation, rice-duck farming, and organic matter return on rice dry matter accumulation and nitrogen utilization. Frontiers in Plant Science, 8: 47. https://doi.org/10.3389/fpls.2017.00047

[14] Villagrán, E.A., Romero, E.J.B., Bojacá, C.R. (2019). Transient CFD analysis of the natural ventilation of three types of greenhouses used for agricultural production in a tropical mountain climate. Biosystems Engineering, 188: 288-304 https://doi.org/10.1016/j.biosystemseng.2019.10.026

[15] Akrami, M., Salah, A.H., Javadi, A.A., Fath, H.E., Hassanein, M.J., Farmani, R., Negm, A. (2020). Towards a sustainable greenhouse: Review of trends and emerging practices in analysing greenhouse ventilation requirements to sustain maximum agricultural yield. Sustainability, $\quad$ 12(7): https://doi.org/10.3390/su12072794

[16] Okushima, L.S.S.N.M., Sase, S., Nara, M. (1988). A support system for natural ventilation design of greenhouses based on computational aerodynamics. In International Symposium on Models for Plant Growth, Environmental Control and Farm Management in Protected Cultivation 248: 129-136. https://doi.org/10.17660/actahortic.1989.248.13

[17] Flores-Velázquez, J., Guerrero, F.V., López, I.L., Montero, J.I., Piscia, D. (2013). 3-Dimensional thermal analysis of a screenhouse with plane and multi-span roof by using computational fluid dynamics (CFD). Acta Horticulturae, 1008: 151-158. https://doi.org/10.17660/ActaHortic.2013.1008.19

[18] Mistriotis, A., Arcidiacono, C., Picuno, P., Bot, G., Scarascia-Mugnozza, G. (1997). Computational analysis of ventilation in greenhouses at zero- and low-windspeeds. Agricultural and Forest Meteorology, 88(1-4): 121-135. https://doi.org/10.1016/S0168-1923(97)000452.

[19] Mistriotis, A., Bot, G., Picuno, P., Scarascia-Mugnozza, G. (1997). Analysis of the efficiency of greenhouse ventilation using computational fluid dynamics. Agricultural and Forest Meteorology, 85(3-4): 217-228.
https://doi.org/10.1016/S0168-1923(96)02400-8

[20] Boulard, T., Haxaire, R., Lamrani, M.A., Roy, J.C., Jaffrin, A. (1999). Characterization and modelling of the air fluxes induced by natural ventilation in a greenhouse. Journal of Agricultural Engineering Research, 74(2): 135-144. https://doi.org/10.1006/jaer.1999.0442

[21] Bournet, P.E., Boulard, T. (2010). Effect of ventilator configuration on the distributed climate of greenhouses: A review of experimental and CFD studies. Computers and Electronics in Agriculture, 74(2): 195-217. https://doi.org/10.1016/j.compag.2010.08.007

[22] Teitel, M., Liron, O., Haim, Y., Seginer, I. (2007). Flow through inclined and concertina-shape screens. Acta Horticulturae, 801: 99-106. https://doi.org/10.17660/ActaHortic.2008.801.5

[23] Tanny, J., Teitel, M., Barak, M., Esquira, Y., Amir, R. (2008). The effect of height on screenhouse microclimate. Acta Horticulturae, 801: 107-114. https://doi.org/10.17660/ActaHortic.2008.801.6

[24] Villagrán, E., Ramirez, R., Rodriguez, A., Pacheco, R.L., Jaramillo, J. (2020). Simulation of the thermal and aerodynamic behavior of an established screenhouse under warm tropical climate conditions: A numerical approach. International Journal of sustainable development and Planning, 15: 487-499. https://doi.org/10.18280/ijsdp.150409

[25] Mupambi, G., Anthony, B.M., Layne, D.R., Musacchi, S., Serra, S., Schmidt, T., Kalcsits, L.A. (2018). The influence of protective netting on tree physiology and fruit quality of apple: A review. Scientia Horticulturae, 236:

60-72. https://doi.org/10.1016/j.scienta.2018.03.014

[26] Villagrán, E.A., Jaramillo, J.E., León-Pacheco, R.I. (2020). Natural ventilation in greenhouse with anti-insect screens evaluated with a computational fluid model. Agronomía Mesoamericana, 31(3): 698-717. https://doi.org/10.15517/AM.V31I3.40782

[27] Flores-Velazquez, J., Villarreal Guerrero, F., Lopez, I.L., Montero, J.I., Piscia, D. (2013). 3-D thermal analysis of a screenhouse with plane and multispan roof by using computational fluid dynamics (CFD). Acta Horticulturae, 1008: 151-158. https://doi.org/10.17660/ActaHortic.2013.1008.19

[28] Villagrán, E. (2021). Two-dimensional numerical study of the microclimate generated in three screenhouses for the climatic conditions of the Colombian Caribbean. International Journal of Heat and Technology, 39(2): 460-468. https://doi.org/10.18280/ijht.390215

[29] Villagrán, E.A., Noreña, J.E.J. (2020). Microclimatic behavior of a screen house proposed for horticultural production in low-altitude tropical climate conditions. Comunicata Scientiae, 11: e3350-e3350. https://doi.org/10.14295/cs.v11i.3350

[30] Villagrán, E.A., Matarrita, R.R., Noreña, J.E.J. (2020). Comportamiento microclimático diurno, en temporada seca, de tres estructuras para agricultura protegida en el trópico seco. UNED Research Journal, 12(2): e2854e2854. https://doi.org/10.22458/urj.v12i2.2854

[31] Villagrán, E., Rodriguez, A. (2021). Analysis of the thermal behavior of a new structure of protected agriculture established in a region of tropical climate $\begin{array}{lll}\text { conditions. } & \text { Fluids, } & \end{array}$ https://doi.org/10.3390/fluids6060223

[32] Teitel, M., Wenger, E. (2012). The effect of screenhouse 
roof shape on the flow patterns - CFD simulations. Acta Horticulturae, 927: 603-610. https://doi.org/10.17660/ActaHortic.2012.927.74

[33] Valera, D.L., Molina, F.D., Álvarez, A.J., López, J.A., Terrés-Nicoli, J.M., Madueño, A. (2005). Contribution to characterisation of insect-proof screens: Experimental measurements in wind tunnel and CFD simulation. Acta Horticulturae, 691: 441-448. https://doi.org/10.17660/ActaHortic.2005.691.53

[34] Wu, T., Lei, C. (2016). CFD simulation of the thermal performance of an opaque water wall system for Australian climate. Solar Energy, 133: 141-154. https://doi.org/10.1016/J.SOLENER.2016.04.001

[35] Baxevanou, C., Fidaros, D., Bartzanas, T., Kittas, C. (2018). Yearly numerical evaluation of greenhouse cover materials. Computers and Electronics in Agriculture, 149: 54-70.

https://doi.org/https://doi.org/10.1016/j.compag.2017.12 .006

[36] Bartzanas, T., Katsoulas, N., Kittas, C. (2012). Solar radiation distribution in screenhouses: A CFD approach, Acta Horticulturae. 956: 449-456. https://doi.org/10.17660/ActaHortic.2012.956.52

[37] Mesmoudi, K., Meguellati, K., Bournet, P.E. (2017). Thermal analysis of greenhouses installed under semi arid climate. International Journal of Heat and Technology, $35(3)$ : $474-486$. https://doi.org/10.18280/ijht.350304

[38] Yu, Y., Xu, X., Hao, W. (2018). Study on the wall optimization of solar greenhouse based on temperature field experiment and CFD simulation. International Journal of Heat and Technology. 36(3): 847-854. https://doi.org/10.18280/ijht.360310

[39] Perén, J.I., van Hooff, T., Leite, B.C.C., Blocken, B. (2016). CFD simulation of wind-driven upward cross ventilation and its enhancement in long buildings: Impact of single-span versus double-span leeward sawtooth roof and opening ratio. Building and Environment, 96: 142156. https://doi.org/10.1016/j.buildenv.2015.11.021

[40] Kim, R.W., Hong, S.W., Lee, I.B., Kwon, K.S. (2017). Evaluation of wind pressure acting on multi-span greenhouses using CFD technique, part 2: Application of the CFD model. Biosystems Engineering, 164: 257-280. https://doi.org/10.1016/J.BIOSYSTEMSENG.2017.09.0 11

[41] He, X., Wang, J., Guo, S., Zhang, J., Wei, B., Sun, J., Shu, S. (2018). Ventilation optimization of solar greenhouse with removable back walls based on CFD. Computers and Electronics in Agriculture, 149: 16-25. https://doi.org/10.1016/j.compag.2017.10.001

[42] ANSYS Fluent, V.18.0. (2020). Ansys Fluent Tutorial Guide.

http://users.abo.fi/rzevenho/ansys\%20fluent $\% 2018 \% 20 t$ utorial\%20guide.pdf.

[43] Khaoua, S.O., Bournet, P.E., Migeon, C., Boulard, T., Chassériaux, G. (2006). Analysis of greenhouse ventilation efficiency based on computational fluid dynamics. Biosystems Engineering, 95(1): 83-98. https://doi.org/10.1016/j.biosystemseng.2006.05.004

[44] Flores-Velazquez, J., Villarreal Guerrero, F., Lopez, I.L., Montero, J.I., Piscia, D. (2012). 3-Dimensional thermal analysis of a screenhouse with plane and multispan roof by using computational fluid dynamics (CFD). In 1st International Symposium on CFD Applications in
Agriculture,

1008:

$151-158$

https://doi.org/10.17660/ActaHortic.2013.1008.19

[45] Reynafarje, X., Villagrán, E.A., Bojacá, C.R., Gil, R., Schrevens, E. (2018). Simulation and validation of the airflow inside a naturally ventilated greenhouse designed for tropical conditions. In XXX International Horticultural Congress IHC2018: III International Symposium on Innovation and New Technologies in Protected, 1271: $55-62$. https://doi.org/10.17660/ActaHortic.2020.1271

[46] Villagrán, E., Bojaca, C.R. (2019). CFD simulation of the increase of the roof ventilation area in a traditional colombian greenhouse: Effect on air flow patterns and thermal behavior. International Journal of Heat and Technology, 37(3): 881-892. https://doi.org/10.18280/ijht.370326

[47] Villagrán, E., Flores-Velazquez, J., Bojacá, C., Akrami, M. (2021). Evaluation of the microclimate in a traditional Colombian greenhouse used for cut flower production. Agronomy, $11(7)$ : 1330. https://doi.org/10.3390/agronomy11071330

[48] Villagrán, E.A., Bojacá, C.R. (2019). Effects of surrounding objects on the thermal performance of passively ventilated greenhouses. Journal of Agricultural Engineering, $\quad 50(1)$ : https://doi.org/10.4081/jae.2019.856

[49] Villagrán, E., Bojacá, C., Akrami, M. (2021). Contribution to the sustainability of agricultural production in greenhouses built on slope soils: A numerical study of the microclimatic behavior of a typical Colombian structure. Sustainability, 13(9): 4748. https://doi.org/10.3390/su13094748

[50] Teitel, M., Liang, H., Vitoshkin, H., Tanny, J., Ozer, S. (2020). Airflow patterns and turbulence characteristics above the canopy of a tomato crop in a roof-ventilated insect-proof screenhouse. Biosystems Engineering, 190: 184-200.

https://doi.org/10.1016/j.biosystemseng.2019.12.001

[51] Pakari, A., Ghani, S. (2019). Evaluation of a novel greenhouse design for reduced cooling loads during the hot season in subtropical regions. Solar Energy, 181: 234-242. https://doi.org/10.1016/j.solener.2019.02.006

[52] Flores-Velazquez, J., Arzeta, A., Ojeda, W., VillarrealGuerrero, F. (2018). Computational fluid dynamics analysis of the wind drag force in a typical Mexican screenhouse. Acta Horticulturae, 1227: 99-106. https://doi.org/10.17660/ActaHortic.2018.1227.12

[53] Teitel, M. (2010). Using computational fluid dynamics simulations to determine pressure drops on woven screens. Biosystems Engineering, 105(2): 172-179. https://doi.org/10.1016/j.biosystemseng.2009.10.005

[54] Ma, D., Carpenter, N., Maki, H., Rehman, T.U., Tuinstra, M.R., Jin, J. (2019). Greenhouse environment modeling and simulation for microclimate control. Computers and Electronics in Agriculture, 162: 134-142. https://doi.org/10.1016/j.compag.2019.04.013

[55] Espinoza, K., López, A., Valera, D.L., Molina-Aiz, F. D., Torres, J.A., Pena, A. (2017). Effects of ventilator configuration on the flow pattern of a naturally ventilated three-span Mediterranean greenhouse. Biosystems Engineering, 164: 13-30. https://doi.org/10.1016/j.biosystemseng.2017.10.001

[56] Al-Mulla, Y.A., Al-Balushi, M., Al-Rawahy, M., AlRaisy, F., Al-Makhmary, S. (2007). Screenhouse 
microclimate effects on cucumber production planted in soilless culture (open system). Acta Horticulturae, 801: 637-644.

https://doi.org/10.17660/ActaHortic.2008.801.73

[57] Tanny, J., Cohen, S., Teitel, M. (2003). Screenhouse microclimate and ventilation: an experimental study. Biosystems Engineering, 84(3): 331-341. https://doi.org/10.1016/S1537-5110(02)00288-X

[58] Zorzeto, T.Q., Leal, P.A.M., Nunes, E.F., de Araújo, H.F. (2014). Homogeneity of temperature and relative humidity of air in greenhouse. International Proceedings of Chemical, Biological and Environmental Engineering (IPCBEE), 79:

25-29. https://doi.org/10.7763/IPCBEE.2014.V79.5

[59] Xu, G., Liu, X., Wang, Q., Xiong, R., Hang, Y. (2017). Effects of screenhouse cultivation and organic materials incorporation on global warming potential in rice fields. Environmental Science and Pollution Research, 24(7): 6581-6591. https://doi.org/10.1007/s11356-017-8397-7

[60] Saberian, A., Sajadiye, S.M. (2019). The effect of dynamic solar heat load on the greenhouse microclimate using CFD simulation. Renewable Energy, 138: 722-737. https://doi.org/10.1016/j.renene.2019.01.108

[61] Fernández, M.D., Bonachela, S., Orgaz, F., Thompson, R., López, J.C., Granados, M.R., Fereres, E. (2010). Measurement and estimation of plastic greenhouse reference evapotranspiration in a Mediterranean climate. $\begin{array}{lll}\text { Irrigation } & \text { Science, } & \text { 28(6): }\end{array}$ https://doi.org/10.1007/s00271-010-0210-z

\section{NOMENCLATURE}

$\begin{array}{ll}\text { IP-SH } & \text { Insect-proof screenhouses } \\ \mathrm{CFD} & \text { Computational fluid dynamics } \\ \mathrm{V}_{\text {in }} & \text { Mean velocity }\left(\mathrm{ms}^{-1}\right) \\ x, y \text { and } z & \text { Coordinates in Cartesian space } \\ C f & \text { Inertial factor of the screen } \\ \mathrm{g} & \text { Gravitational acceleration, }\left(\mathrm{m} \cdot \mathrm{s}^{-2}\right) \\ \mathrm{k} & \text { Thermal conductivity }\left(\mathrm{W} \cdot \mathrm{m}^{-1} \cdot \mathrm{K}^{-1}\right) \\ \mathrm{K} & \text { Permeability of the porous medium } \\ \text { Vnor } & \text { The normalized wind speed } \\ \mathrm{MAE} & \text { Absolute mean error }\left({ }^{\circ} \mathrm{C}, \%\right) \\ \mathrm{RMSE} & \text { Root Mean square error }\left({ }^{\circ} \mathrm{C}, \%\right) \\ \mathrm{S}_{\phi} & \text { Source term } \\ \mathrm{T}_{\text {in }} & \text { Mean temperature inside }\left({ }^{\circ} \mathrm{C}\right) \\ \mathrm{u}, \mathrm{v} \text { and } & \text { Components of speed }\left(\mathrm{ms} \mathrm{s}^{-1}\right) \\ \mathrm{w} & \\ \mathrm{DO} & \text { Discrete ordinate model } \\ \mathrm{S} & \text { Scenario } \\ \end{array}$

\section{Greek symbols}

$\begin{array}{ll}\Gamma_{\phi} & \text { The diffusion coefficient } \\ \Delta \mathrm{Tm} & \text { Thermal gradient }\left({ }^{\circ} \mathrm{C}\right) \\ \varnothing & \text { Variable of interest } \\ k & \text { Turbulent kinetic energy } k\left(\mathrm{~m}^{2} \mathrm{~s}^{-3}\right) \\ \varepsilon & \text { Turbulent kinetic energy dissipation rate }\left(\mathrm{m}^{2} \cdot \mathrm{s}^{-3}\right) \\ \mu & \text { dynamic viscosity }\left(\mathrm{kg} \cdot \mathrm{m}^{-1} \cdot \mathrm{s}^{-1}\right) \\ \nabla^{2} & \text { Laplacian operator } \\ \rho_{0} & \text { density }\left(\mathrm{Kg} \cdot \mathrm{m}^{-3}\right)\end{array}$

